\title{
Physiological and biochemical response to Omega-3 plus as a dietary supplement to growing goats under hot summer conditions
}

\author{
Fatma Edrees Ibrahim Teama', Akram A. El-Tarabany ${ }^{1}$
}

${ }^{1}$ Atomic Energy Authority, Nuclear Research Center, Department of Biological Applications, Inshas, Cairo, Egypt.

\begin{abstract}
The objective of the present study was to assess the effect of dietary supplementation of Omega-3 plus on some the physiological and biochemical traits in growing Baladi goats under hot summer conditions. Thirty-four growing male goats (4-5 months old) were randomly divided into two equal groups. Animals in group 1 were fed a concentrate feed mixture (CFM), which was the control group. Goats in group 2 (the experimental group) were offered Omega-3 plus $\left(1,000 \mathrm{mg} /\right.$ animal $\left.\mathrm{day}^{-1}\right)(30 \%$ fish oil, containing $18 \%$ eicosapentaenoic acid and $12 \%$ docosahexaenoic acid $+100 \mathrm{mg}$ wheat germ oil $(0.22 \%$ tocopherols $))$ daily in addition to the basal diet for four months (the experimental period) during the hot summer season. Body weight (BW) changes of both groups were recorded monthly during the experiment. Blood samples were collected monthly, and total protein, immunoglobulin G (IgG), total cholesterol, triglycerides, liver enzymes (AST and ALT), blood urea nitrogen, serum creatinine, and thyroid hormones $\left(\mathrm{T}_{3}\right.$ and $\left.\mathrm{T}_{4}\right)$ were estimated. A significant increase in the live BW of growing goats was recorded as a result of dietary supplementation of Omega- 3 plus. Total protein, $\mathrm{IgG}$, and $\mathrm{T}_{3}$ levels were higher than those obtained with control. In contrast, total cholesterol, triglycerides, urea, ALT, and AST levels were significantly reduced. The serum concentration of creatinine and $\mathrm{T}_{4}$ levels was indistinguishable from those of control. Addition of Omega-3 plus as a dietary supplement to growing goats under hot summer conditions increases their daily weight gain and improves their general physiological and biochemical status by decreasing total cholesterol, triglycerides, urea, ALT, and AST. It is thus suggested that Omega-3 plus should be used as a supplement in the growth period of goats.
\end{abstract}

Key Words: cholesterol, heat stress, IgG, liver enzymes, $\mathrm{T}_{3}, \mathrm{~T}_{4}$

\section{Introduction}

In tropical and subtropical regions with high ambient temperatures throughout the year, heat stress is considered one of the main factors affecting the viability and sustainability of livestock production (Gaughan et al., 2009). It has been shown that goats are better adapted than other domesticated ruminants to heat stress (Devendra, 1990). Heat stress affects almost all body systems, physiologically (Marai et al., 2007), biochemically (Spurlock and Savage, 1993), and hormonally (Helal et al., 2010).

The main essential omega-3 fatty acids are eicosapentaenoic acid (EPA), docosahexaenoic acid (DHA), and $\alpha$-linoleic acid (ALA). Unfortunately, mammals have limited ability to synthesize omega-3 fatty acids, which are necessary for their health benefits (Kris-Etherton et al., 2002). It is well known that dietary

Received June 5, 2015 and accepted February 28, 2016

Corresponding author: fatema58us@yahoo.com

http://dx.doi.org/10.1590/S1806-92902016000400005

Copyright (C) 2016 Sociedade Brasileira de Zootecnia. This is an Open Access article distributed under the terms of the Creative Commons Attribution License (http://creativecommons.org/licenses/by/4.0/), which permits unrestricted use, distribution, and reproduction in any medium, provided the original work is properly cited. omega-3 has an important role in the maintenance of the structure of cellular membranes, improving the absorption of liposoluble vitamins (A, D, E, and K), reducing plasma triglycerides, regulating the cholesterol metabolism, and producing eicosanoids, which regulate various cellular processes (vascular and bronchial tone, gastrointestinal and uterine motility, gastric protection, urine output, blood clotting, body temperature, and inflammatory and immune processes (Ponnampalam et al., 2001). Dietary omega-3 fatty acids are also essential for normal growth and metabolism (Kris-Etherton et al., 2002). Omega-3 fatty acids have anti-oxidant effects that play a critical role in the development and functioning of the central nervous system (Logan, 2004).

Wheat germ oil (WGO) is known to be one of the richest sources of polyunsaturated fatty acids; it contains vitamin E, which prevents oxidation products of unsaturated fatty acids, and octacosanol. Wheat germ oil has been recommended as a dietary supplement for farm animals (Barnes, 1983), as an additive in health products to change plasma and liver cholesterol (Kahlon et al., 1988), or to promote physical endurance and retard aging (Kahlon, 1989). Wheat germ oil was used as a breeding aid for livestock and poultry (Kahlon, 1989), in which it is considered a natural source of alpha-tocopherols (Kring and Berger, 2001). 
Because of the limited studies addressing the effect of omega-3 on physiological and biochemical traits of goats, this study focused on the physiological and biochemical response to Omega-3 plus in diets for growing goats in the Egyptian hot summer season.

\section{Material and Methods}

This study was undertaken in Inshas, Egypt. Experimental animals were healthy and clinically free of external and internal parasites and were fed the available basal diet, which consisted of a concentrate feed mixture (CFM), according to NRC (1985) recommendations for goats. The diet (Table 1) was offered once daily at $10.00 \mathrm{~h}$, at $3.5 \%$ of the body weight of the experimental animals.

Fresh drinking water was available ad libitum. The experimental animals were allocated to two groups, housed under a semi-roofed yard, and kept under the same feeding and management conditions. Animals were weighed at the beginning of the experiment at monthly intervals thereafter. The current study was approved by the institutional review board.

Thirty-four weaning young Baladi male goats aged 4-5 months, with an average weight of $6.5 \pm 0.2 \mathrm{~kg}$, were randomly divided into two equal experimental groups. Animals were fed for two weeks, as a transitional period, before the start of the experimental work. Animals in the 1st group (control) were fed the basal diet, without any additives, whereas each animal from the 2 nd group (experimental group) was fed the basal diet and orally supplemented capsulated medium-level Omega 3-plus

Table 1 - Ingredients of the concentrate feed mixture (CFM) and chemical composition of feedstuffs used in the experiment

\begin{tabular}{lcc}
\hline Item & $\begin{array}{c}\text { CFM } \\
\left(\mathrm{g} \mathrm{kg}^{-1} \text { as fed }\right)\end{array}$ & $\begin{array}{c}\text { Berseem hay } \\
\left(\mathrm{g} \mathrm{kg}^{-1} \text { as fed }\right)\end{array}$ \\
\hline Concentrate ingredient & & \\
Crushed yellow maize & 27 & \\
Wheat bran & 374 & \\
Soybean meal & 124 & \\
Undecorticated cotton seed meal & 100 & \\
Rice bran & 50 & \\
Sugarcane molasses & 40 & \\
Limestone & 30 & \\
Sodium chloride & 10 & \\
Mineral mixture and vitamins & 2 & 168.8 \\
Chemical composition of the feedstuffs & & 210.4 \\
Dry matter & 904.6 & 16.3 \\
Crude protein & 185 & 446.1 \\
Crude fiber & 134.6 & 841.6 \\
Ether extract & 48.5 & 158.4 \\
Nitrogen-free extract & 536.9 & \\
Organic matter & 905 & \\
Ash & 905 & \\
\hline
\end{tabular}

according to Okukpe et al. (2011) (1,000 mg [30\% fish oil, containing $18 \%$ eicosapentaenoic acid and $12 \%$ docosahexaenoic acid] $+100 \mathrm{mg}$ wheat germ oil $(0.22 \%$ tocopherols)). The Omega-3 plus was purchased from the Sedico company (Egypt). The experiment began after the end of the weaning period during the hot summer season, in May, and continued for four months (the experimental length), until August (2013). The body weight of all animals was recorded once monthly.

Air temperature $\left({ }^{\circ} \mathrm{F}\right)$ and relative humidity $(\%)$ on the farm were measured once weekly, at four times, at 12.00, $13.00,14.00$, and $15.00 \mathrm{~h}$, using a digital thermo-hygrometer. Temperature-humidity index (THI) values were calculated according to LPHSI (1990), using the formula below:

$$
\mathrm{THI}=\mathrm{DB}-([0.55-0.55 \times \mathrm{RH}][\mathrm{DB}-58]),
$$

in which $\mathrm{DB}=$ dry bulb temperature, in Fahrenheit; and $\mathrm{RH}=$ relative humidity $(\% / 100)$. The obtained values can be interpreted as follows: $>72=$ no heat stress (comfortable); $72<78=$ moderate heat stress; $78<86=$ severe heat stress; and $>86=$ very severe heat stress (Marai et al., 2000). The estimated average monthly air temperature $\left({ }^{\circ} \mathrm{F}\right)$ was $93.5,94.5,95.0$, and 92.5 , and relative humidity (\%) was 52.0, 56.0, 59.0, and 60.0 in May, June, July, and August, respectively. The corresponding THI values were 84.13 , $85.67,86.64$, and 87.25 , indicating that the Baladi kids suffered from severe heat stress during May and June and very severe heat stress during July and August.

Blood samples were collected monthly before the supply of the morning feed during the experimental period in vacuum tubes without anticoagulant. To obtain the serum, tubes were centrifuged at 3,000 rpm for $20 \mathrm{~min}$ and stored at $-20{ }^{\circ} \mathrm{C}$ until analysis. Serum total protein, total cholesterol, triglycerides, aspartate aminotransferase (AST), alanine aminotransferase (ALT), urea, and creatinine were determined using commercial kits (Bio-Diagnostic, Egypt). Serum immunoglobulin $\mathrm{G}(\operatorname{IgG})$ was measured using the kit from Binding Site Ltd. (Birmingham, UK). The levels of serum thyroid hormones $\left(\mathrm{T}_{3}\right.$ and $\left.\mathrm{T}_{4}\right)$ were estimated by the radioimmunoassay (RIA) technique, using coated tube kits (Diagnostic Systems Laboratories, Inc. Webster, Texas, USA) and counting in a laboratory, using computerized Gamma Counter. The tracer in the hormones was labeled with iodine-125 ( $\left.{ }^{125} \mathrm{I}\right)$.

The economic gain was calculated as the market values of the total income from gain, feed cost, and cost of Omega-3 plus in four months. Values quoted at the time of the experiment were used to calculate the feed cost per kilogram in the local currency, that is, Egyptian pounds (LE). One US dollar was equivalent to 7.60 LE. Feed cost per kilogram (\$), total cost of feedstuffs $(\$)$, feed cost per 
kilogram of weight gained (\$), and net income (total income - expenditure) were calculated.

Data were expressed as means \pm standard error. Differences between the mean values of treated and control groups were calculated using the unpaired varieties of the $\mathrm{t}$ test of significance on SAS (Statistical Analysis System, version 8.02). $\mathrm{P} \leq 0.05$ was considered significant.

The following statistical model was employed:

$$
\mathrm{Y}_{\mathrm{ij}}=\mu+\mathrm{T}_{\mathrm{i}}+\mathrm{e}_{\mathrm{ij}}
$$

in which $\mathrm{Y}=$ dependent variable; $\mu=$ overall mean; $\mathrm{T}_{\mathrm{i}}=$ fixed effect of treatment; and $\mathrm{e}_{\mathrm{ij}}=$ random error.

\section{Results}

The overall DMI from CFM and berseem hay increased significantly, by about $13 \%(\mathrm{P}=0.014)$ and $5 \%(\mathrm{P}=0.059)$ when Baladi male goats received Omega-3 plus for four months in the summer season (Table 2). A significant increase was recorded in live body weight (LBW) and daily body weight gain (DBW) of the animals fed Omega-3 plus. The increase in LBW started in the second month of treatment $(1.45 \mathrm{~kg} ; \mathrm{P}=0.001)$, rising after three and four months. The overall increase in LBW and DBW was $7.8 \mathrm{~kg}$ and $131.09 \mathrm{~g}$, respectively (Table 3).

A significant decrease was observed in total cholesterol level from the second to the fourth month of treatment $(\mathrm{P}=0.001)$ compared with control (untreated) animals under the same condition. A decrease in triglycerides was also reported during the four months of the summer season in the same animals $(\mathrm{P}=0.001)$ compared with control group (Table 4). A significant decrease $(P=0.01)$ in the level of liver enzymes (AST and ALT) as well as blood urea was

Table 2 - Effect of Omega-3-plus supplement on daily voluntary dry matter intake (DMI, g/day head ${ }^{-1}$ ) from feedstuffs by growing male Baladi goats during hot summer conditions

\begin{tabular}{lccccc}
\hline \multirow{2}{*}{$\begin{array}{l}\text { Experimental } \\
\text { month }\end{array}$} & Feedstuff & \multicolumn{4}{c}{$\begin{array}{c}\text { Average DMI from feedstuffs } \\
(\mathrm{g} / \text { day head })^{-1}\end{array}$} \\
\cline { 3 - 6 } & & Control & $\begin{array}{c}\text { Omega-3 } \\
\text { plus }\end{array}$ & P-value & $\begin{array}{c}\text { Change } \\
(\%)\end{array}$ \\
\hline 1st month & CFM & $22.4 \pm 0.30$ & $26.9 \pm 0.50$ & 0.049 & +20.1 \\
& Berseem hay & $2.2 \pm 0.20$ & $2.5 \pm 0.20$ & 0.038 & +13.6 \\
2nd month & CFM & $34.4 \pm 0.30$ & $40.9 \pm 0.30$ & 0.011 & +18.89 \\
& Berseem hay & $2.7 \pm 0.10$ & $2.9 \pm 0.10$ & 0.063 & - \\
3rd month & CFM & $55.9 \pm 0.70$ & $60.6 \pm 0.40$ & 0.019 & +8.40 \\
4th month & Berseem hay & $3.4 \pm 0.30$ & $3.4 \pm 0.20$ & 0.74 & - \\
& CFM & $46.4 \pm 0.50$ & $51.9 \pm 0.30$ & 0.016 & +11.85 \\
Overall mean & CFM & $39.77 \pm 1.82$ & $45.07 \pm 1.48$ & 0.014 & +13.33 \\
& Berseem hay & $2.8 \pm 0.12$ & $2.95 \pm 0.13$ & 0.059 & +5.35 \\
\hline
\end{tabular}

CFM - concentrate feed mixture. observed during the four experimental months in animals supplemented with Omega-3plus compared with their corresponding control animals during the hot summer season. However, serum creatinine concentration did not show any significant changes between both groups (Table 5).

Total proteins and $\mathrm{IgG}$ were determined in the blood of growing male goats in the hot summer climate. The data showed a significant increase $(\mathrm{P}=0.01)$ in both proteins during the entire experimental period in the treated animals compared with control (Table 6). No significant changes were reported in the level of $\mathrm{T}_{4}$ hormone for both groups of animals examined in the present study. However, a significant increase $(\mathrm{P}=0.02)$ was noted in the level of $\mathrm{T}_{3}$ hormone for animals that received Omega-3 plus compared with control during the summer season (four months) (Table 7).

Table 3 - Effect of Omega-3-plus supplement on live body weight and daily gain of growing male Baladi goats under hot summer conditions

\begin{tabular}{|c|c|c|c|c|c|}
\hline \multirow{2}{*}{$\begin{array}{l}\text { Experimental } \\
\text { month }\end{array}$} & \multicolumn{2}{|c|}{ Experimental group } & \multicolumn{3}{|c|}{ Changes due to omega- 3 plus } \\
\hline & Control & $\begin{array}{l}\text { Omega-3 } \\
\text { plus }\end{array}$ & Significance & $\begin{array}{c}\text { Change } \\
(\%)\end{array}$ & $\begin{array}{l}\text { Monthly } \\
\text { increase }\end{array}$ \\
\hline \multicolumn{6}{|c|}{ Live body weight (kg) } \\
\hline $1 \mathrm{st}$ & $6.65 \pm 0.34$ & $6.42 \pm 0.33$ & 0.630 & -3.4 & -0.23 \\
\hline 2nd & $8.94 \pm 0.40$ & $10.39 \pm 0.57$ & 0.001 & 16.21 & +1.45 \\
\hline $3 \mathrm{rd}$ & $11.74 \pm 0.35$ & $14.69 \pm 0.84$ & 0.002 & 25.17 & +2.95 \\
\hline 4th & $15.22 \pm 0.32$ & $18.89 \pm 0.84$ & 0.006 & 24.11 & +3.67 \\
\hline Overall & & & & & +7.84 \\
\hline \multicolumn{6}{|c|}{ Daily body weight gain (g) } \\
\hline $1 \mathrm{st}$ & - & - & - & - & $\begin{array}{c}\text { Daily } \\
\text { increase }\end{array}$ \\
\hline 2nd & $76.27 \pm 4.6$ & $133.3 \pm 5.5$ & 0.001 & 74.77 & +57.03 \\
\hline $3 \mathrm{rd}$ & $93.13 \pm 3.0$ & $143.3 \pm 6.4$ & 0.014 & 53.87 & +50.17 \\
\hline 4th & $116.08 \pm 4.6$ & $140.0 \pm 6.9$ & 0.002 & 20.60 & +23.92 \\
\hline Overall & & & & & +131.09 \\
\hline
\end{tabular}

Significant difference at $\mathrm{P}<0.05$.

Table 4 - Effect of Omega-3-plus supplement on cholesterol and triglycerides concentration in growing male Baladi goats under hot summer conditions

\begin{tabular}{lcccc}
\hline \multirow{2}{*}{$\begin{array}{l}\text { Experimental } \\
\text { month }\end{array}$} & \multicolumn{2}{c}{ Experimental group } & Change \\
\cline { 2 - 3 } & Control & Omega-3 plus & & \\
\hline \multicolumn{5}{c}{ Cholesterol (mg/dL) } \\
1st & $75.23 \pm 2.2$ & $72.15 \pm 1.91$ & 0.30 & - \\
2nd & $63.35 \pm 2.2$ & $57.15 \pm 1.92$ & 0.04 & -9.78 \\
3rd & $73.23 \pm 2.2$ & $64.96 \pm .1 .04$ & 0.002 & -11.29 \\
4th & $68.23 \pm 2.2$ & $59.96 \pm 1.04$ & 0.001 & -12.12 \\
& \multicolumn{5}{c}{ Triglycerides (mg/dL) } & \\
1st & $19.58 \pm 0.68$ & $14.39 \pm 0.29$ & 0.001 & -26.50 \\
2nd & $21.02 \pm 0.80$ & $14.94 \pm 0.29$ & 0.001 & -22.07 \\
3rd & $21.27 \pm 0.80$ & $15.19 \pm 0.29$ & 0.001 & -28.58 \\
4th & $21.60 \pm 0.80$ & $15.52 \pm 0.29$ & 0.001 & -28.14 \\
\hline
\end{tabular}

Significant difference at $\mathrm{P}<0.05$. 


\section{Discussion}

During the last decades, goat meat has gained growing interest due to its preferable nutritional features, as it contains low levels of fat and cholesterol (Madruga and Bressan, 2011) and a higher level of polyunsaturated fatty acids (PUFA) compared with beef or lamb (Banskalieva and Goetsch, 2000). The naturally high level of PUFA may indicate that goat has a potential to deposit high n-3 PUFA levels in its tissues. Enriching goat meat with n-3 PUFA

Table 5 - Effect of Omega-3-plus supplement on liver and kidney functions of growing male Baladi goats under hot summer conditions

\begin{tabular}{|c|c|c|c|c|}
\hline \multirow{2}{*}{$\begin{array}{l}\text { Experimental } \\
\text { month }\end{array}$} & \multicolumn{2}{|c|}{ Experimental group } & \multirow{2}{*}{ Significance } & \multirow{2}{*}{$\begin{array}{c}\text { Change } \\
(\%)\end{array}$} \\
\hline & Control & Omega-3 plus & & \\
\hline \multicolumn{5}{|c|}{ Aspartate aminotransferase (IU/L) } \\
\hline 1 st & $78.70 \pm 1.6$ & $48.43 \pm 1.4$ & 0.001 & -38.46 \\
\hline 2nd & $80.36 \pm 1.6$ & $50.09 \pm 1.4$ & 0.001 & -37.66 \\
\hline $3 \mathrm{rd}$ & $82.69 \pm 1.7$ & $52.42 \pm 1.5$ & 0.001 & -36.75 \\
\hline 4th & $85.69 \pm 1.7$ & $55.42 \pm 1.6$ & 0.001 & -35.32 \\
\hline \multicolumn{5}{|c|}{ Alanine aminotransferase (IU/L) } \\
\hline 1 st & $20.81 \pm 0.76$ & $17.84 \pm 0.83$ & 0.01 & -14.27 \\
\hline 2nd & $21.55 \pm 0.75$ & $18.28 \pm 0.82$ & 0.01 & -16.96 \\
\hline $3 \mathrm{rd}$ & $22.10 \pm 0.76$ & $19.13 \pm 0.83$ & 0.01 & -13.43 \\
\hline 4th & $23.65 \pm 0.77$ & $20.68 \pm 0.84$ & 0.01 & -12.55 \\
\hline \multicolumn{5}{|c|}{ Urea $(\mathrm{mg} / \mathrm{dL})$} \\
\hline 1 st & $46.14 \pm 0.76$ & $29.32 \pm 0.64$ & 0.01 & -36.45 \\
\hline 2nd & $47.80 \pm 0.77$ & $30.98 \pm 0.65$ & 0.01 & -35.18 \\
\hline $3 \mathrm{rd}$ & $49.13 \pm 0.76$ & $32.31 \pm 0.66$ & 0.01 & -34.23 \\
\hline 4 th & $49.87 \pm 0.76$ & $33.05 \pm 0.64$ & 0.01 & -33.72 \\
\hline \multicolumn{5}{|c|}{ Creatinine $(\mathrm{mg} / \mathrm{dL})$} \\
\hline 1 st & $0.58 \pm 0.02$ & $0.60 \pm 0.02$ & 0.60 & - \\
\hline 2nd & $0.59 \pm 0.02$ & $0.62 \pm 0.02$ & 0.57 & - \\
\hline $3 \mathrm{rd}$ & $0.63 \pm 0.02$ & $0.65 \pm 0.02$ & 0.66 & - \\
\hline 4th & $0.68 \pm 0.02$ & $0.70 \pm 0.02$ & 0.73 & - \\
\hline
\end{tabular}

Significant difference at $\mathrm{P}<0.05$.

Table 6 - Effect of Omega-3-plus supplement on total protein and immunoglobulin of growing male Baladi goats under hot summer conditions

\begin{tabular}{llllc}
\hline \multirow{2}{*}{$\begin{array}{l}\text { Experimental } \\
\text { month }\end{array}$} & \multicolumn{2}{c}{ Experimental group } & Significance & $\begin{array}{c}\text { Change } \\
(\%)\end{array}$ \\
\cline { 2 - 3 } & Control & Omega-3 plus & & \\
& \multicolumn{5}{c}{ Total protein (g/dL) } \\
1st & $6.19 \pm 0.12$ & $6.59 \pm 0.15$ & 0.05 & +6.46 \\
2nd & $6.38 \pm 0.15$ & $6.92 \pm 0.14$ & 0.01 & +8.46 \\
3rd & $6.63 \pm 0.15$ & $7.17 \pm 0.16$ & 0.01 & +8.14 \\
4th & $7.18 \pm 0.15$ & $7.72 \pm 0.16$ & 0.01 & +7.52 \\
& \multicolumn{4}{c}{ Immunoglobulin (g/dL) } \\
1st & $0.73 \pm 0.01$ & $0.86 \pm 0.03$ & 0.002 & +17.80 \\
2nd & $0.74 \pm 0.01$ & $0.88 \pm 0.03$ & 0.002 & +18.91 \\
3rd & $0.79 \pm 0.01$ & $0.92 \pm 0.03$ & 0.001 & +16.45 \\
4th & $0.85 \pm 0.01$ & $0.98 \pm 0.03$ & 0.01 & +15.29 \\
\hline
\end{tabular}

Significant difference at $\mathrm{P}<0.05$. together with its natural favorable nutritional characteristics allows goat meat to play an important role in human health as a functional food, especially for health-conscious consumers. However, information about the effects of the feeding regime on the profiles of edible tissues of goat is usually relatively scarce (Lee and Kannan, 2012).

The current study focuses on the effects of supplementation of encapsulated Omega-3 plus on physiological and biochemical traits during summer months. Dry matter intake is the amount that an animal must consume from a diet that contains the recommended energy concentration for the animal life stage and the production level.

According to the present study, DMI increased significantly (Table 2) with the supply of capsulated Omega-3 plus to Baladi male goat during hot summer months. This increase may be due to the long-term feeding of four months, or to the low level of Omega-3 plus. Indeed, Okukpe et al. (2011) found that the omega-3 fatty acids increase feed intake and feed efficiency when supplemented at different levels to Dwarf goats for eight weeks. However, this increase failed to achieve a statistical significance. The significant increase in DMI with capsulated Omega-3 plus observed in this study may be attributed to the oral supply of delayed-release capsule, and this may lead to increased appetite and increase feed intake (Okukpe et al., 2011). Gastrointestinal side effects of omega-3 intake include eructation and increased appetite (http://www.drugs. com/sfx/omega-3-side-effects.html) and good absorption in the intestinal tract. Feeding supplemental capsulated Omega-3 plus makes the fat partially inert in the rumen and sometimes can prevent a depression in DMI. It can allow specific fatty acids to escape ruminal biohydrogenation and then become available in the small intestine for absorption

Table 7 - Effect of Omega-3-plus supplement on thyroid hormones $\left(\mathrm{T}_{3}\right.$ and $\mathrm{T}_{4}$ ) concentrations of growing male Baladi goats under hot summer conditions

\begin{tabular}{lcccc}
\hline $\begin{array}{l}\text { Experimental } \\
\text { month }\end{array}$ & \multicolumn{2}{c}{ Experimental group } & Significance & $\begin{array}{c}\text { Change } \\
(\%)\end{array}$ \\
\cline { 2 - 3 } & Control & Omega-3 plus & & \\
\hline & & $\mathrm{T}_{3}(\mathrm{ng} / \mathrm{mL})$ & & +24.35 \\
1st & $0.78 \pm 0.02$ & $0.97 \pm 0.07$ & 0.02 & +22.61 \\
2nd & $0.84 \pm 0.02$ & $1.03 \pm 0.07$ & 0.02 & +21.59 \\
3rd & $0.88 \pm 0.02$ & $1.07 \pm 0.07$ & 0.03 & +20.21 \\
4th & $0.94 \pm 0.02$ & $1.13 \pm 0.07$ & 0.02 & - \\
& & & & - \\
1st & $51.64 \pm 1.6$ & $51.12 \pm 1.5$ & 0.81 & - \\
2nd & $53.41 \pm 1.5$ & $52.89 \pm 1.5$ & 0.80 & - \\
3rd & $55.74 \pm 1.6$ & $55.22 \pm 1.6$ & 0.66 & \\
4th & $59.30 \pm 1.6$ & $58.78 \pm 1.6$ & 0.63 & \\
\hline
\end{tabular}

Significant difference at $\mathrm{P}<0.05$. 
and utilization. Providing fatty acids in capsule form may reduce a deficiency and act on target tissues in addition to increasing the energy density of the diet (Cullens, 2005).

A significant increase in LBW and DBW was recorded in animals treated with Omega-3 plus compared with control group. The current study, therefore, revealed an improvement in body weight gain in the growing goats that received of Omega-3-plus supplementation. It was previously reported that using supplemental fat might improve the energy balance and increase birth weight in shame goats (Titi and Awad, 2007; Eghoghosoa et al., 2011). Fatty acid supplements may also improve the ability to use nutrients from the food and convert them into muscle protein (Simopoulos, 2002). A study conducted by Okukpe et al. (2011) confirmed the present finding, in which they observed an improvement of weight gain in goats fed omega-3 fatty acid as a supplement, but this correlation did not achieve significance. In general, feeding omega-3 fatty acid may improve the health status of animals for four months, as described previously (Stewart, 2006).

According to our results, it was observed that the effect of omega-3 plus on the biochemical parameters during the summer season was a significant decrease in total cholesterol and triglyceride levels in goats fed Omega-3 plus during the summer months compared with control animals (Table 4). It was noted that omega-3 fatty acid has a major effect on plasma lipid by reducing the triglyceride content (Mattos et al., 2000). In addition, a slight (non-statistical significance) decrease in cholesterol level in goats treated with omega-3 fatty acid was recorded (Okukpe et al., 2011). The exact mechanism by which omega-3 fatty acid affects serum lipids is not completely understood. Simopouls et al. (1992) stated that cholesterol and triglycerides are reduced through inhibition of biosynthesis of very low-density lipoprotein (VLDL) and triglycerides in the liver, in which EPA and DHA are considered bad substrates for enzymes responsible for triglyceride synthesis. It was also reported that it may inhibit the esterification of other fatty acids needed for the triglyceride synthesis (Harris and Bulchandani, 2006).

Liver enzymes (ALT and AST) as well as kidney function (urea) were significantly improved by supplementation of Omega-3 plus for growing Baladi goats during hot summer months. However, the serum concentration of creatinine was indistinguishable from that of control treatment (Table 5). It has been reported that addition of EPA and DHA improves kidney status by attenuating or even reversing the loss of kidney functions and reduces hypertension in the kidney in general (Donadio et al., 1994). Both low- and high-dose EPA and DHA were similar in slowing the rate of renal function loss (Donadio et al., 2001). Pettersson et al. (1994) found a decline in renal function when supplementing $3.3 \mathrm{~g}$ of $\mathrm{EPA} / 1.8 \mathrm{~g}$ of DHA for six months. In addition, studies have demonstrated that omega-3 fatty acid treatment decreased blood pressure and led to slow renal failure and moderate the side effects of hypertension (Imig et al., 2005; Zhao et al., 2004). However, Fassett et al. (2010) failed to establish any role of omega-3 fatty acids on prevention of kidney diseases. In contrast, conflicting results were reported in a recent study by Okukpe et al. (2011), in which the level of urea nitrogen was elevated in animals receiving omega-3. Habeeb et al. (1992) stated that the change in urea concentrations could be attributed to increases in protein synthesis, decreased protein degradation, or a combination of both. In addition, under hot summer conditions, the reduction of plasma urea may cause an increase in plasma volume as a result of heat shock and subsequently the increase in blood volume leads to maintenance of both homeothermy peripheral vasodilation and sweating (Khalil et al., 1990). This increase in plasma volume (hemodilution) in high-temperature environments caused a decrease in plasma urea.

Plasma total proteins and IgG concentrations increased significantly during the months of hot summer season as a result of supplementation of Omega-3 plus in the diet of Baladi kids (Table 6). These results showed that addition of Omega-3 plus to the diet of Baladi goats improved the animal immunity function and restored physiologically relevant levels of protein function. Immunoglobulin is the main component of antibodies; an increase in the $\mathrm{IgG}$ level indicates a good immune status of the animal. As regards the fact that fatty acids act as reservoirs for potent biologically active molecules and that they regulate the environment of membrane-bound proteins, it is not surprising that they affect many organs and their functions. Altogether, the general shift to the phenotype of reduced responses and reactivity in cells and tissues enriched with these lipids may explain the general health-promoting properties of these dietary fats (Ballou et al., 2009).

Omega-3 plus supplementation to the Baladi goat kids increased the $T_{3}$ level significantly during the months of hot summer season (Table 7). Thyroid hormones, which are mainly implicated in the regulation of tissue growth and metabolism, are influenced by many factors, including nutrition. This is supported by the finding of Vanderpas (2006), who concluded that the increase in basal metabolic rate is accompanied by increased appetite and subsequently increased body weight. The $\mathrm{T}_{4}$ hormone was not significantly affected; these results suggested that the enzymes directly or indirectly promoted an enhanced activity of deiodinase in the liver and kidney tissues, providing the transformation 
of $\mathrm{T}_{4}$ into the biologically active hormone $\mathrm{T}_{3}$ (Calder, 2012). This, in turn, was responsible for the increased metabolic rates and accelerated growth of the kids. In addition, Lomenick et al. (2008) confirmed the present results, suggesting that $\mathrm{T}_{3}$ values were good indicators of growth changes. It appears that exogenous enzymes increased the blood concentrations of $\mathrm{T}_{3}$ and correspondingly changed the concentrations of $\mathrm{T}_{4}$.

The best use of the absorbed nutrients was achieved when Omega-3 plus was incorporated into the goat diet and, at the same time, the profit over the feed cost was higher by around $28 \%$ in the Omega- 3 plus-supplemented diet (Table 8).

Table 8 - Economic gain per animal during the experimental period (four months) with Omega-3-plus supplementation to Baladi goat kids in summer conditions

\begin{tabular}{lcc}
\hline \multirow{2}{*}{ Economic indicator } & \multicolumn{2}{c}{ Experimental group } \\
\cline { 2 - 3 } & Control & Omega-3 plus \\
\hline Total gain $(\mathrm{kg})$ & 8.57 & 12.47 \\
Total income from gain $(\$)$ & 44.93 & 65.4 \\
Concentrate feed mixture $(\mathrm{CFM})(\mathrm{kg})$ & 84.5 & 96.2 \\
Berseem hay $(\mathrm{BH})(\mathrm{kg})$ & 6.5 & 9.60 \\
Cost of feedstuffs $(\$)$ & 28.54 & 32.8 \\
Cost of Omega-3 plus in four months (\$) & - & 11.4 \\
Total expenditure & 223.5 & 337.1 \\
Net income = Total income - Expenditure & 119.3 & 161.7 \\
Percentage of gain over control & 100 & 135.54 \\
\hline
\end{tabular}

Price of kg live body weight $=\$ 5.20$; Price of Omega- 3 plus $=\$ 0.33$; Price of feedstuffs $(\mathrm{CFM}$ and $\mathrm{BH})=\$ 0.33$ and $\$ 0.13$, respectively, quoted in Egypt in 2013.

\section{Conclusions}

Supplementation of Omega-3 plus for growing male Baladi goat kids for four months is beneficial, improving different physiological and biochemical functions by decreasing total cholesterol, triglycerides, alanine aminotransferase, aspartate aminotransferase, and urea during the Egyptian summer season without causing any kind of stress to the health of the animals. Omega-3-plus can be used as dietary supplement for Baladi goat kids.

\section{Acknowledgments}

The authors would like to thank Dr. Hassan Fargaly, professor of animal physiology, Nuclear Research Center, for providing the animals from the goat unit of Experimental Farm Project; and Dr. Hussein el-Zaher (Goat Farm), Nuclear Research Center, Atomic Energy Authority, Inshas.

\section{References}

Ballou, M. A.; Cruz G. D.; Pittroff, W.; Keisler, D. H. and De Peters, E. J. 2009. Modifying the acute phase response of Jersey calves by supplementing milk replacer with omega-3 fatty acids from fish oil. Journal of Dairy Science 91:3478-3487.

Banskalieva, T. S. and Goetsch, A. L. 2000. Fatty acid composition of goat muscles and fat depots: a review. Small Ruminant Research $37: 255-268$

Barnes, P. J. 1983. Wheat germ oil. p.64-72. In: Lipids in cereal technology. Barnes, P. J., ed. Academic, London, UK.

Calder, P. C. 2012. Mechanisms of action of (n-3) fatty acids. Nutratnion 142:592S-599S

Cullens, F. M. 2005. Effect of the timing of initiation of fat supplementation on productive and reproductive responses of periparturient dairy cows during summer. Thesis (M. Sc.). University of Florida, Gainesville, FL, USA.

Devendra C. 1990. Comparative aspects of digestive physiology and nutrition in goats and sheep. p.45-60. In: Ruminant nutrition and physiology in Asia. Devendra C. and Imaizumi, E., eds. Japanese Society of Zootechnical Science, Sendai.

Donadio, J. V.; Bergstralh, E. J.; Offord, K. P.; Holley, K. E. and Spencer, D. C. 1994. Clinical and histopathological associations with impaired renal function in IgA nephropathy. Mayo Nephrology Collaborative Group. Clinical Nephrology 41:65-71.

Donadio, J. V.; Larson, T. S. and Bergstralh, E. J. 2001. A randomized trial of high-dose compared with low-dose omega-3 fatty acids in severe IgA nephropathy. American Journal of Society Nephrol $12: 791-9$

Eghoghosoa, A. R.; Aderemi, O. L.; Olufemi, S. A. and Peter O. I. 2011. Effect of angiotensin I-converting enzyme inhibitor captopril on body weight, food and water consumption in oral contraceptivetreated rats. American Journal of Biochemistry and Molecular Biology 1:95-100

Fassett, R. G.; Gobe, G. C.; Peake, J. M. and Coombes, J. S. 2010. Omega-3 polyunsaturated fatty acids in the treatment of kidney disease. American Journal of Kidney Diseases 56:728-42.

Gaughan, J. B.; Lacetera, N.; Valtorta, S. E.; Khalifa, H. H.; Hahn, L. and Mader, T. 2009. Response of domestic animals to climate challenges. p.131-170. In: Biometeorology of adaptation to climate variability and change. Ebi, K. B.; Burton, I. and McGregor, G. R., eds. Springer Science, Heidelberg, Germany.

Habeeb, A. A. M.; Marai, I. P. M. and Kamal, T. H. 1992. Heat stress. p.27-47. In: Farm animals and the environment. Phillips, C. and Piggins, D., eds. CABI Publishing, Wallingford, UK.

Harris, W. S. and Bulchandani, D. 2006. Why do omega-3 fatty acids lower serum triglycerides Currant Opin Lipids 17:387-393.

Helal, A.; Hashem, A. L.; Abdel-Fattah, M. S. and El-Shaer, A. M. 2010. Effects of heat stress on coat characteristics and physiological responses of baladi and Damascus goat in Sinai Egypt. American Euresian Journal of Agriculture and Environmental Science 7:60-69.

Imig, J. D.; Zhao, X. and Zaharis, C. Z. 2005. An orally active epoxide hydrolase inhibitor lowers blood pressure and provides renal protection in salt-sensitive hypertension. Journal of Hypertension 46:975-981.

Kahlon, T. S. 1989. Nutritional implications and uses of wheat and oat kernel oil. Cereal Foods World 34:872-875.

Kahlon, T. S.; Chow, F. L.; Chiu, M. M. and Betschart, A. A. 1988. Induce of wheat and oat fractions on rat plasma-cholesterol and triglycerides. Cereal Foods World 33:686-691.

Khalil, M. H.; El-Gabbas, H. M.; Khalifa, H. S. and Abdel-Fattah, M. S. 1990. Effect of exposure to solar radiation on some 
physiological and hematological parameters in local and crossbred sheep. Egyptian Journal of Animal Production 27:47-60.

Kring, U. and Berger, R. G. 2001. Antioxidant activity of some roasted foods. Journal of Food Chemistry 72:223-229.

Kris-Etherton, P. M; Harris, W. S. and Appel, L. J. 2002. Fish consumption, fish oil, omega-3 fatty acids and cardiovascular disease. Circulation 106:2747-2757.

Lee, J. H. and Kannan, G. 2012. Influences of diets on fatty acid composition of edible tissues of meat goat. p.250-259. In: Goat meat production and quality. Mahgoub, O.; Kadim, I. T. and Webb, E. C., eds. CABI, Cambridge, MA, USA.

Logan, A. C. 2004. Omega-3 fatty acids and major depression: A primer for the mental health professional. Lipids in Health and Diseases 3:1-8

Lomenick, J. P.; El-Sayed, M. and Smit, W. J. 2008. Effect of levothyroxine treatment on weight and body mass index in children with acquired hypothyroidism. Journal of Pediatric 152:96-100.

LPHSI - Livestock and Poultry Heat Stress Indices. 1990. Agriculture engineering technology guide. Clemson University, Clemson, SC, USA.

Madruga, M. S. and Bressan, M. C. 2011. Goat meats: description, rational use, certification, processing and technological developments. Small Ruminant Research 98:39-45.

Marai, I. F. M.; Bahgat, L. B.; Shalaby, T. H. and Abdel-Hafez, M. A. 2000. Fattening performance, some behavioral traits and physiological reactions of male lambs fed concentrates mixture alone with or without natural clay, under hot summer of Egypt. Annals of Arid Zone 39:449-460.

Marai, F. M.; El-Darawany A. A.; Fadiel, A.; Abdel Hafez, M. A. 2007. Physiological traits as affected by heat stress in sheep a review. Small Ruminant Research 71:1-12.

Mattos R. C.; Staples, R. and Thatcher, W. W. 2000. Effects of dietary fatty acids on reproduction in ruminants. Journal of Review Reproduction 5:38-45.
NRC - National Research Council. 1985. Nutrient requirements of sheep. 6th ed. National Academy Press, Washington, DC.

Okukpe, K. M.; Adeloye, A. A.; Yousef, M. B; Alli, O. I.; Belewu, M. A. and Adeyina, O. A. 2011. Physiological response of West African Dwarf goats to oral supplementation with Omega-3-fatty acid. Asian Journal of Animal Science 5:365-372.

Pettersson A.; Eriksson L. and Lundh H. 1994. No short-term difference in outcome after temporomandibular joint arthrography alone or with immediate lavage. Oral Surge Oral Med Oral Pathology 77:322-326.

Ponnampalam, E. N.; Sinclair, A. J.; Egan A. R.; Blakeley, S. J. and Leary, B. J. 2001. Effect of diets containing $n-3$ fatty acids on muscle long-chain $n-3$ fatty acid content in lambs fed low- and mediumquality roughage diets. Journal of Animal Science 79:698-706.

Simopoulos, A. P. 2002. Omega-3 fatty acids in inflammation and autoimmune diseases. Journal of American Cell Nutrition 21:459-505.

Simopoulos, A. P.; Norman H. A.; Gillaspy, J. E. and Duke, J. A. 1992. Common purslane: a source of omega-3 fatty acids and antioxidants. Journal of the American College of Nutrition 11:374-382.

Spurlock, M. E. and Savage, J. E. 1993. Effects of dietary protein and selected antioxidants on fatty hemorrhagic syndrome induced in Japanese quails. Poultry Science 72:2095-2105.

Stewart, J. F. 2006. Food supplement and use thereof for elevating levels of essential fatty acids in livestock and products there form. U.S. Patent No. 7001610, PATENT STORM LLC.

Titi, H. H. and Awad, R. 2007. Effect of dietary fat supplementation on reproductive performance of goats. Journal of Animal Reproduction 4:23-30.

Vanderpas, J. 2006. Nutritional epidemiology and thyroid hormone metabolism. Annual Review of Nutrition 26:293-322.

Zhao, X.; Yamamoto, T. and Newman, J. W. 2004. Soluble epoxide hydrolase inhibition protects the kidney from hypertensioninduced damage. Journal of the American Society of Nephrology $15: 1244-1253$ 